\title{
Naringin protects against steroid-induced avascular necrosis of the femoral head through upregulation of PPAR $\gamma$ and activation of the Notch signaling pathway
}

\author{
DONGHONG HUANG ${ }^{1 *}$, ZHANCHUN LI $^{1 *}$, BIN CHEN $^{2 *}$, GUIZHEN FANG ${ }^{1}$, \\ XITAO SUN ${ }^{1}$, FEI LI $^{1}$, HAIRU XU ${ }^{1}$, YING CHEN $^{1}$ and WEIHANG DING ${ }^{1}$ \\ ${ }^{1}$ Department of Orthopedics, Zhejiang Provincial Hospital of TCM, Hangzhou, Zhejiang 310006; ${ }^{2}$ Department of Orthopedics, \\ The First Affiliated Hospital, Shantou University Medical College, Shantou, Guangdong 515041, P.R. China
}

Received October 3, 2016; Accepted June 1, 2017

DOI: $10.3892 / \mathrm{mmr} .2017 .8247$

\begin{abstract}
Naringin, a flavonoid, is the effective pharmaceutical ingredient of drynaria, with the effects of healing fractures, strengthening bones and promoting kidney function. The aim of the present study was to investigate the potential effect of naringin on steroid-induced avascular necrosis of the femoral head (SANFH). Treatment with naringin markedly protected against the steroid-induced decrease in serum osteocalcin levels, and the rate of osteonecrosis in a model of SANFH. In addition, naringin decreased the total cholesterol and low density lipoprotein/high density lipoprotein ratio in the SANFH rabbit. It was observed that naringin markedly inhibited caspase-3 activity, increased runt-related transcription factor 2 and transcription factor sp7 mRNA expression, promoted alkaline phosphatase activity and upregulated collagen I, peroxisome proliferator-activated receptor (PPAR) $\gamma 2$, neurogenic locus notch homolog protein (Notch), $\beta$-catenin and phosphorylated-Rac- $\alpha$ serine/threonine protein kinase protein expression in the SANFH rabbit. The results of the present study demonstrated that naringin protects against SANFH through upregulation of PPAR $\gamma 2$ and activation of the Notch signaling pathway, and may be a useful addition to the treatment options for diseases of the femoral head.
\end{abstract}

Correspondence to: Dr Weihang Ding, Department of Orthopedics, Zhejiang Provincial Hospital of TCM, 54 Youdian Road, Hangzhou, Zhejiang 310006, P.R. China

E-mail: dqew1322738@126.com

Mr. Bin Chen, Department of Orthopedics, The First Affiliated Hospital, Shantou University Medical College, 57 Changping Road, Shantou, Guangdong 515041, P.R. China

E-mail: cb2126313@sina.com

${ }^{*}$ Contributed equally

Key words: naringin, steroid-induced avascular necrosis of the femoral head, peroxisome proliferator-activated receptor $\gamma 2$, neurogenic locus notch homolog protein

\section{Introduction}

Femoral head disease $(\mathrm{FH})$ is one of the refractory diseases in the field of orthopedics, which may be clinically divided into invasive and non-invasive categories; the former is primarily due to skeletal trauma, including femoral neck fracture or hip dislocation, and the latter is principally caused by the application of corticosteroids and long-term heavy alcohol consumption $(1,2)$. Steroid-induced FH is the most common type of non-invasive $\mathrm{FH}$, accounting for $50 \%$ of mortalities (3). Hormones are widely-used in the anti-inflammatory treatment of severe acute infections. Hormone treatment may prevent certain sequelae of inflammation, autoimmune diseases, including severe rheumatic fever, rheumatic myocarditis, rheumatic and rheumatoid arthritis, systemic lupus erythematosus, autoimmune anemia and nephrotic syndrome, organ transplant rejection, and allergic diseases, including urticaria, angioedema, bronchial asthma and anaphylactic shock; therefore, high-dose or long-term use of hormones may lead to FH $(2,3)$. It is of particular importance that effective marrow protection treatment methods be identified, and early diagnosis and intervention holds the greatest promise for the treatment of steroid-induced FH.

FH is one of the most serious complications of glucocorticoid therapy, and, in recent years, research has focused on the etiology, pathology and pathogenesis of the disease, particularly the theories of fat metabolism, intravascular coagulation, bone high pressure and osteoporosis, to provide novel approaches towards pharmaceutical prevention and early intervention for steroid-induced FH (4). However, precise mechanisms underlying steroid-induced $\mathrm{FH}$ remain unclear; although different theories have emerged from clinical and experimental research, they cannot explain all the clinical phenomena and experimental results, and it is therefore important to investigate the exact pathogenesis of steroid-induced FH, and develop sensitive early diagnostic methods, effective early treatment or preventative approaches (4).

Peroxisome proliferator-activated receptor (PPAR) $\gamma$ is a ligand-activated nuclear transcription factor, which belongs to the PPAR superfamily. The aldehyde reductase (ARY) gene, located on chromosome $3 \mathrm{p} 25$, may be divided into three 
subtypes: ARY1, present in numerous tissues; PPARY3, highly expressed in macrophages, adipocytes and colonic epithelial cells; and PPAR $\gamma$ (5), primarily expressed in fat cells, with relative specificity (6). Previous experimental results have demonstrated that ARY serves an important role in the differentiation of bone marrow stromal cells, and that PPARY3 is considered to regulate the differentiation of bone marrow stromal cells into adipocytes, and is the necessary differentiation-specific transcription factor for the generation of fat cells (7). PPAR $\gamma$ serves a positive role in the regulation of the differentiation of bone marrow stromal cells into adipocytes, and an increased expression level in bone marrow stromal cells may promote the formation of adipocytes, subsequently leading to $\mathrm{FH}(8)$.

The neurogenic locus notch homolog protein 1 (Notch1) signaling pathway serves an important role in the differentiation of human bone marrow mesenchymal stem cells into neuronal cells. It has been reported that the Notch1-mediated signaling pathway is the essential factor in determining the differentiation potential of bone marrow mesenchymal stem cells (9). The weakening of Notch signaling pathway is associated with the proliferation and differentiation of bone marrow mesenchymal stem cells in osteoporosis patients following the menopause, which may be one of the causes for the decrease in postmenopausal bone mass of patients with osteoporosis (10). Estrogen may reverse the decreased expression of important molecules in the Notch signaling pathway of bone marrow mesenchymal stem cells in postmenopausal osteoporotic patients; following treatment with estrogen, the expression of receptor Notch1 and its ligand protein jagged-1 is increased, and the expression of transcription factor HES1 is increased markedly. It is therefore indicated that an association may exist between estrogen and the Notch signaling pathway (10). Following estrogen stimulation in human bone marrow mesenchymal stem cells during the osteogenic and adipogenic differentiation processes, it was previously observed that the expression of key molecules increases compared with a group without estrogen stimulation in the early stage of osteogenic differentiation and adipogenic differentiation (11).

Drynaria (Fig. 1) is the dried rhizome of Drynaria fortunei (Kunze) J. Sm., which was described in 'Herbal Supplements' of the Tang Dynasty as bitter and warm, with the effects of strengthening bones and reinforcing kidney and liver function, alleviating injury and providing analgesia (12). Drynaria is a type of Chinese herbal medicine used to promote fracture healing, and is commonly prescribed for the treatment of osteoporosis (13). Drynaria contains sterols, triterpenes, phenolic acids and a variety of flavonoids, and a previous study demonstrated that drynaria water extract and flavonoids may effectively inhibit bone loss and prevent osteoporosis (14). Naringin is the most abundant flavonoid in drynaria, with a range of biological activities (14). A previous study indicated that naringin may promote proliferation and osteogenic differentiation in human bone marrow mesenchymal stem cells, which serves a role in the proliferation of osteoblasts (15). The present study examined the role of naringin in steroid-induced avascular necrosis of the femoral head (SANFH) with the aim of elucidating the potential modulatory mechanisms.

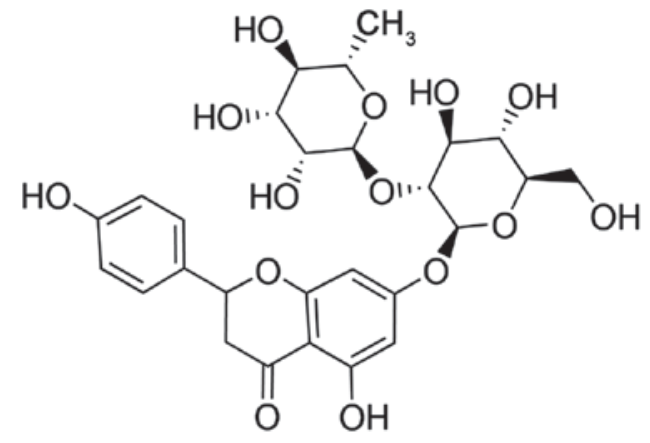

Figure 1. Chemical structure of naringin.

\section{Materials and methods}

Experimental animal and instruments. The Ethics Committee of Zhejiang Provincial Hospital of TCM (Hangzhou, China) approved the present study. A total of 30 male healthy adult Japanese white rabbits ( 5 months old; $2.5 \pm 0.5 \mathrm{~kg}$ ) were provided by the Animal Breeding Center of Shantou University Medical College (Shantou, China) and were kept in a temperature$\left(21 \pm 2^{\circ} \mathrm{C}\right)$ and humidity- $(55 \pm 10 \%)$ controlled room on a 12 -h light/dark cycle. The rabbits were fed with a standard diet with free access to food and water, and housed individually in cages.

Establishment of the experimental animal model and grouping. All the rabbits were randomly divided into 5 groups: Control group ( $\mathrm{n}=6)$; model group $(\mathrm{n}=6) ; 5 \mathrm{mg} / \mathrm{kg}$ naringin group $(\mathrm{n}=6) ; 10 \mathrm{mg} / \mathrm{kg}$ naringin group $(\mathrm{n}=6)$ and $20 \mathrm{mg} / \mathrm{kg}$ naringin group $(n=6)$. A total of three injections of methylprednisolone (MPS; 20 mg/kg body weight; Sigma-Aldrich; Merck KGaA, Darmstadt, Germany) were administered intramuscularly at $24 \mathrm{~h}$ intervals into rabbits to establish the SANFH model. Doses of 5, 10 and $20 \mathrm{mg} / \mathrm{kg}$ naringin (Sigma-Aldrich; Merck $\mathrm{KGaA}$ ) were administered intramuscularly into SANFH model rabbits every week for 8 weeks. In the control group, rats were administered intramuscularly with equal volume of vehicle.

Determination of biological indicator. Femoral head tissue was fixed using 5\%-paraformaldehyde for $24 \mathrm{~h}$ at room temperature and embedded into paraffin. Then, samples were cut into $0.5 \mu \mathrm{M}$ sections, stained with hematoxylin and eosin at $37^{\circ} \mathrm{C}$ for $15 \mathrm{~min}$ and observed using a light microscope. Osteonecrosis was identified by the necrosis of the medullary hematopoietic cells in osteocytes. Osteonecrosis incidence rate was calculated using the amount of osteonecrosis/total amount. SANFH tissue was washed and homogenized using a radioimmunoprecipitation assay (RIPA) buffer (Beyotime Institute of Biotechnology, Haimen, China) on ice for $1 \mathrm{~h}$. Following centrifugation at $12,000 \mathrm{x}$ g for $10 \mathrm{~min}$ at $4^{\circ} \mathrm{C}$, the supernatant was collected to analyze the protein content using a bicinchoninic acid (BCA) assay. The caspase-3 activity was detected with a Caspase-3 Colorimetric Assay kit (cat. no. C1115; Beyotime Institute of Biotechnology), and osteocalcin (cat. no. H152), total cholesterol (cat. no. F002-1), the ratio of low-density lipoprotein to high-density lipoprotein (LDL/HDL ratio; cat. no. A113-1/ A112-1) and alkaline phosphatase (ALP; cat. no. A059-2) activity was detected using Colorimetric Assay kits (Nanjing Jiancheng Bioengineering 

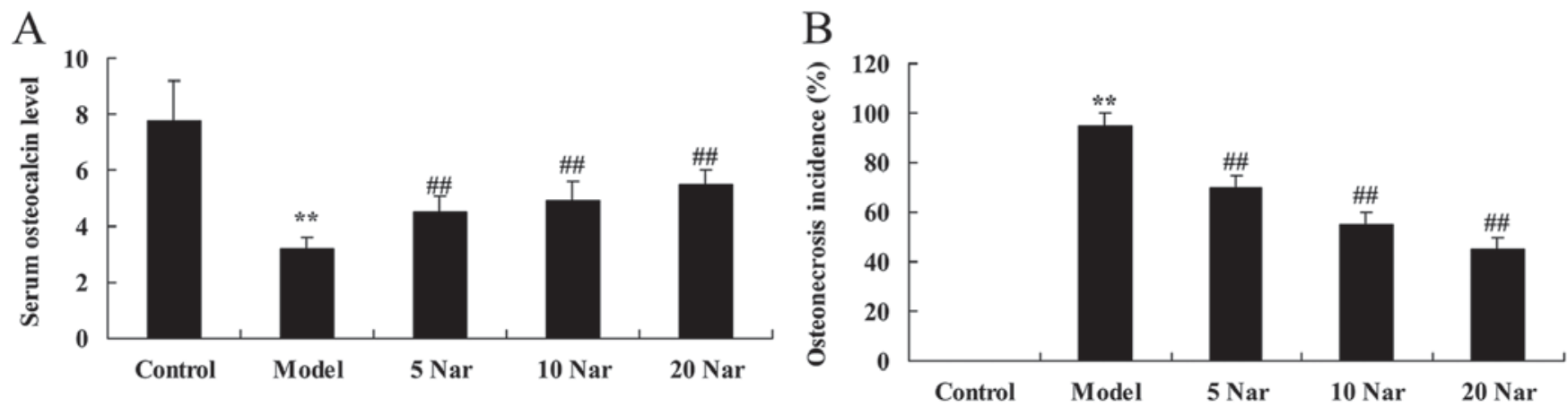

Figure 2. Protective effects of naringin on steroid-induced serum osteocalcin level and osteonecrosis incidence. Treatment with naringin reversed the effects of steroids on the (A) serum osteocalcin level and (B) osteonecrosis incidence rate. ${ }^{* *} \mathrm{P}<0.01$ vs. control group; ${ }^{\# \#} \mathrm{P}<0.01 \mathrm{vs}$. model group. Control, control group; Model, steroid-induced avascular necrosis of the femoral head model group; Nar, naringin; $5 \mathrm{Nar}, 5 \mathrm{mg} / \mathrm{kg}$ naringin treatment group; $10 \mathrm{Nar}, 10 \mathrm{mg} / \mathrm{kg}$ naringin treatment group; $20 \mathrm{Nar}, 20 \mathrm{mg} / \mathrm{kg}$ naringin treatment group.

Institute, Nanjing, China). Caspase-3 activity was expressed in terms of absorbance units [optical density (OD) $405 \mathrm{~nm}$ ], and osteocalcin, total cholesterol, LDL/HDL ratio and ALP activity was expressed in terms of absorbance units (OD $450 \mathrm{~nm}$ ) using an ELISA reader (Beckman Coulter, Inc., Brea, CA, USA).

Reverse transcription-quantitative polymerase chain reaction (RT-qPCR) analysis. Total RNA from the SANFH tissue was isolated using TRIzol ${ }^{\circledR}$ Reagent (Invitrogen; Thermo Fisher Scientific, Inc., Waltham, MA, USA) according to the manufacturer's protocol. Total RNA (500 ng) was synthesized into cDNA using an RT kit, according to the manufacturer's protocol (Fermentas; Thermo Fisher Scientific, Inc.). The 7500 Real-Time PCR system (Bio-Rad Laboratories, Inc., Hercules, CA, USA) was used to perform the qPCR, using Power SYBR-Green PCR Master mix (Bio-Rad Laboratories, Inc.). The PCR program involved 40 cycles of $94^{\circ} \mathrm{C}$ for $15 \mathrm{sec}$, an annealing step at $60^{\circ} \mathrm{C}$ for $30 \mathrm{sec}$, and $72^{\circ} \mathrm{C}$ for $30 \mathrm{sec}$. Primers used were: RUNX2, 5'-AAGTGCGGTGCAAACTTTCT-3' and 5'-TCTCGGTGGCTGCTAGTGA-3', OSX, 5'-GCCAGA AGCTGTGAAACCTC-3' and 5'-GCTGCAAGCTCTCCA TAACC-30), and $\beta$-actin, $5^{\prime}$-TCCTAGCACCATGAAGATC-3' and 5'AAACGCAGCTCAGTAACAG-3' as control. miRNA expression was quantified using the $2^{-\Delta \Delta \mathrm{Cq}}$ method (16).

Western blot analysis. SANFH tissue was washed and homogenized using RIPA buffer on ice for $1 \mathrm{~h}$. Following centrifugation at $12,000 \mathrm{x} \mathrm{g}$ for $10 \mathrm{~min}$ at $4^{\circ} \mathrm{C}$, the supernatant was obtained to analyze the protein content using a BCA assay. Proteins in the lysates $(50 \mu \mathrm{g})$ were subsequently separated via $8-12 \%$ SDS-PAGE 1 and electrophoretically transferred onto polyvinylidene difluoride membranes (Bio-Rad Laboratories, Inc.). The membranes were blocked with $5 \% \mathrm{w} / \mathrm{v}$ non-fat dried milk in TBS/Tween-20 for $1 \mathrm{~h}$ at $37^{\circ} \mathrm{C}$ and incubated with anti-collagen I (cat. no. sc-25974; 1:500), anti-PPAR $\gamma$ (cat. no. sc-9000; 1:500), anti-Notch (cat. no. sc-9170; 1:500), anti- $\beta$-catenin (cat. no. sc-16743-R; 1:500), anti-phosphorylated (p-)Rac- $\alpha$ serine/threonine protein kinase (p-AKT; cat. no. sc-16646-R; 1:500) and anti-GAPDH (cat. no. sc-25778; 1:2,000; all from Santa Cruz Biotechnology, Inc., Dallas, TX, USA), overnight at $4^{\circ} \mathrm{C}$. Membranes were washed with TBS/Tween-20 three times and incubated with anti-rabbit horseradish peroxidase-conjugated secondary polyclonal antibody (cat. no. sc-2004; 1:5,000;
Santa Cruz Biotechnology, Inc.) at room temperature for $1 \mathrm{~h}$. Positive antibody interactions were visualized using an enhanced chemiluminescence-plus kit (Thermo Fisher Scientific Inc.) and quantified using densitometry and Quantity One software version 3.0 (Bio-Rad Laboratories, Inc.).

Statistical analysis. Quantitative data are expressed as the mean \pm standard deviation of 3 independent experiments. Statistical analysis was performed using SPSS software version 17.0 (SPSS, Inc., Chicago, IL, USA). Data were analyzed using one-way analysis of variance followed by Tukey's post test. $\mathrm{P}<0.05$ was considered to indicate a statistically significant difference.

\section{Results}

Protective effects of naringin on steroid-induced serum osteocalcin level and osteonecrosis incidence rate. In the SANFH model group, a significant inhibition of serum osteocalcin was observed, compared with the control group (Fig. 2A). There was a significant increase in osteonecrosis incidence in the SANFH model group, compared with the control group (Fig. 2B). Treatment with naringin increased the serum osteocalcin levels and inhibited osteonecrosis in SANFH rabbits, compared with the SANFH model group (Fig. 2).

Protective effects of naringin on total cholesterol and $L D L / H D L$ cholesterol ratio. The total cholesterol and LDL/HDL cholesterol ratio of the SANFH model group were increased compared with the control group (Fig. 3). Treatment with naringin reversed this increase in total cholesterol and the LDL/HDL cholesterol ratio in SANFH rabbits, compared with the SANFH model group (Fig. 3).

Protective effects of naringin on caspase-3 activity. Compared with the control group, there was a significant increase in caspase-3 activity in the SANFH rabbit model group (Fig. 4). Treatment with naringin significantly suppressed caspase-3 activity in SANFH rabbits, compared with the SANFH model group (Fig. 4).

Protective effects of naringin on runt-related transcription factor 2 (RUNX2) and transcription factor sp7 (OSX) mRNA 

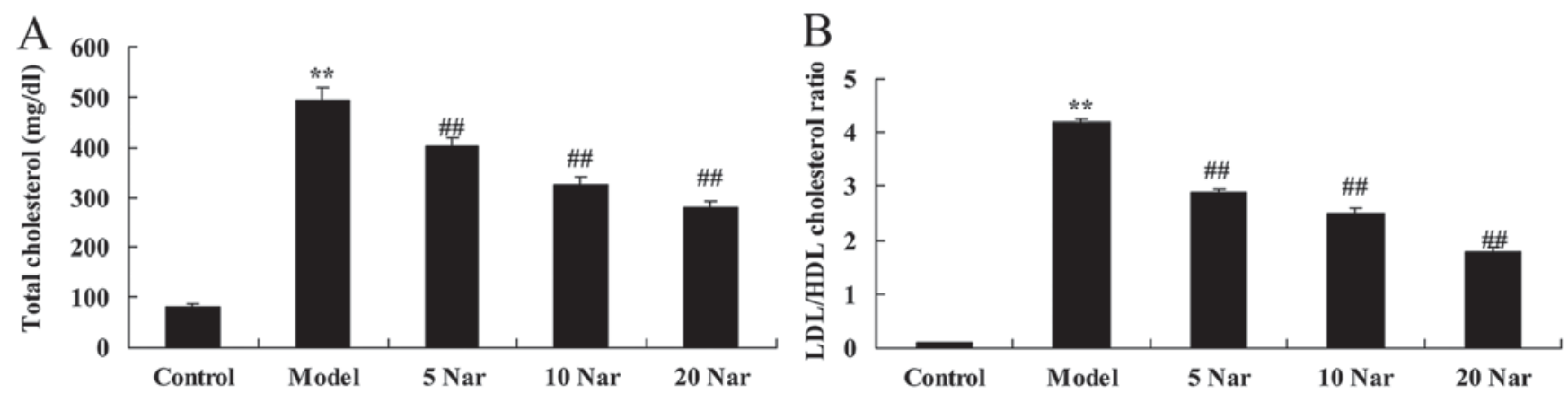

Figure 3. Protective effects of naringin on total cholesterol and LDL/HDL cholesterol ratio. Treatment with naringin reversed the effects of steroids on the (A) total cholesterol and (B) LDL/HDL cholesterol ratio. ${ }^{* *} \mathrm{P}<0.01$ vs. control group; ${ }^{\# \#} \mathrm{P}<0.01$ vs. model group. LDL, low-density lipoprotein; HDL, high-density lipoprotein; Control, control group; Nar, naringin; Model, steroid-induced avascular necrosis of the femoral head model group; 5 Nar, 5 mg/kg naringin treatment group; $10 \mathrm{Nar}, 10 \mathrm{mg} / \mathrm{kg}$ naringin treatment group; $20 \mathrm{Nar}, 20 \mathrm{mg} / \mathrm{kg}$ naringin treatment group.

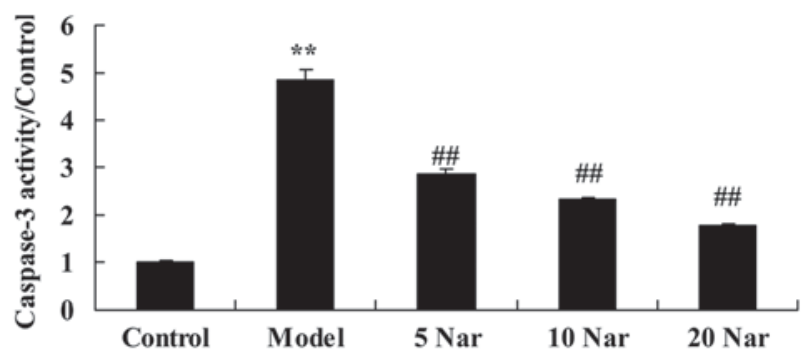

Figure 4. Protective effects of naringin on caspase-3 activity. Treatment with naringin reversed the effects of steroid on caspase- 3 activity. ${ }^{* *} \mathrm{P}<0.01$ vs. control group; ${ }^{\# \#} \mathrm{P}<0.01$ vs. model group. Control, control group; Model, steroid-induced avascular necrosis of the femoral head model group; Nar, naringin; 5 Nar, $5 \mathrm{mg} / \mathrm{kg}$ naringin treatment group; $10 \mathrm{Nar}, 10 \mathrm{mg} / \mathrm{kg}$ naringin treatment group; $20 \mathrm{Nar}, 20 \mathrm{mg} / \mathrm{kg}$ naringin treatment group.
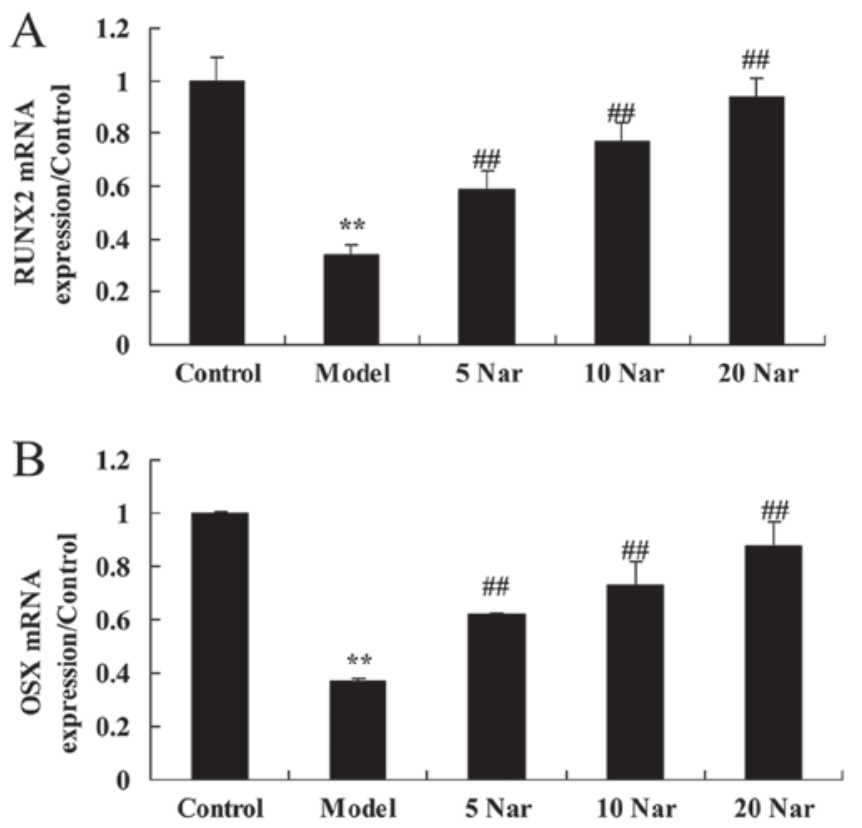

Figure 5. Protective effects of naringin on RUNX2 and OSX mRNA expression. Treatment with naringin reversed the effects of steroids on the expression of (A) RUNX2 and (B) OSX mRNA. ${ }^{* *} \mathrm{P}<0.01$ vs. control group; ${ }^{\# \#} \mathrm{P}<0.01$ vs. model group. RUNX2, runt-related transcription factor 2; OSX, transcription factor sp7; Control, control group; Model, steroid-induced avascular necrosis of the femoral head model group; Nar, naringin; $5 \mathrm{Nar}, 5 \mathrm{mg} / \mathrm{kg}$ naringin treatment group; $10 \mathrm{Nar}, 10 \mathrm{mg} / \mathrm{kg}$ naringin treatment group; $20 \mathrm{Nar}, 20 \mathrm{mg} / \mathrm{kg}$ naringin treatment group.

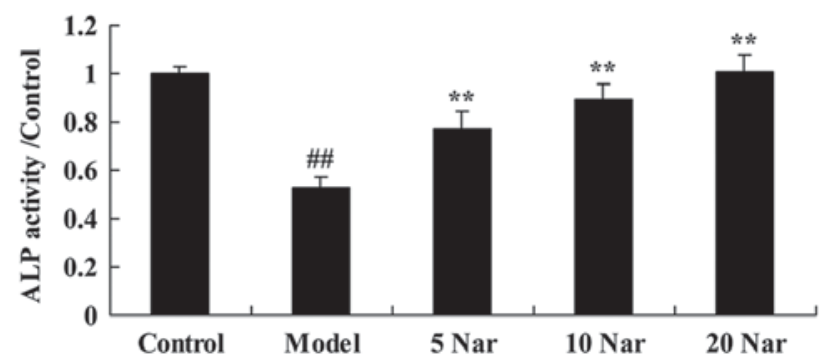

Figure 6. Protective effects of naringin on ALP activity. Treatment with naringin reversed the effects of steroids on ALP activity. ${ }^{\# \#} \mathrm{P}<0.01$ vs. control group; ${ }^{* *} \mathrm{P}<0.01$ vs. model group. ALP, alkaline phosphatase; Control, control group; Model, steroid-induced avascular necrosis of the femoral head model group; $\mathrm{Nar}$, naringin; $5 \mathrm{Nar}, 5 \mathrm{mg} / \mathrm{kg}$ naringin treatment group; $10 \mathrm{Nar}, 10 \mathrm{mg} / \mathrm{kg}$ naringin treatment group; $20 \mathrm{Nar}, 20 \mathrm{mg} / \mathrm{kg}$ naringin treatment group.

expression. RUNX2 and OSX mRNA expression in the SANFH rabbit model group were significantly decreased compared with the control group (Fig. 5). The decrease of RUNX2 and OSX mRNA expression in the SANFH rabbit was significantly reversed by treatment with naringin, compared with the SANFH model group (Fig. 5).

Protective effects of naringin on ALP activity. It was observed that ALP activity was significantly decreased in the SANFH rabbit model group, compared with the control group (Fig. 6). Treatment with naringin significantly improved ALP activity in the SANFH rabbit, compared with the SANFH model group (Fig. 6).

Protective effects of naringin on collagen I protein expression. In addition, it was observed that collagen I protein expression in the SANFH rabbit model was decreased compared with the control group (Fig. 7). Naringin treatment significantly enhanced collagen I protein expression in the SANFH rabbit, compared with the SANFH model group (Fig. 7).

Protective effects of naringin on PPAR $\gamma$ protein expression. As presented in Fig. 8, PPAR $\gamma$ protein expression in the SANFH rabbit model was significantly suppressed, compared with the control group. Naringin significantly promoted PPAR $\gamma$ protein expression in the SANFH rabbit, compared with the SANFH model group (Fig. 8). 

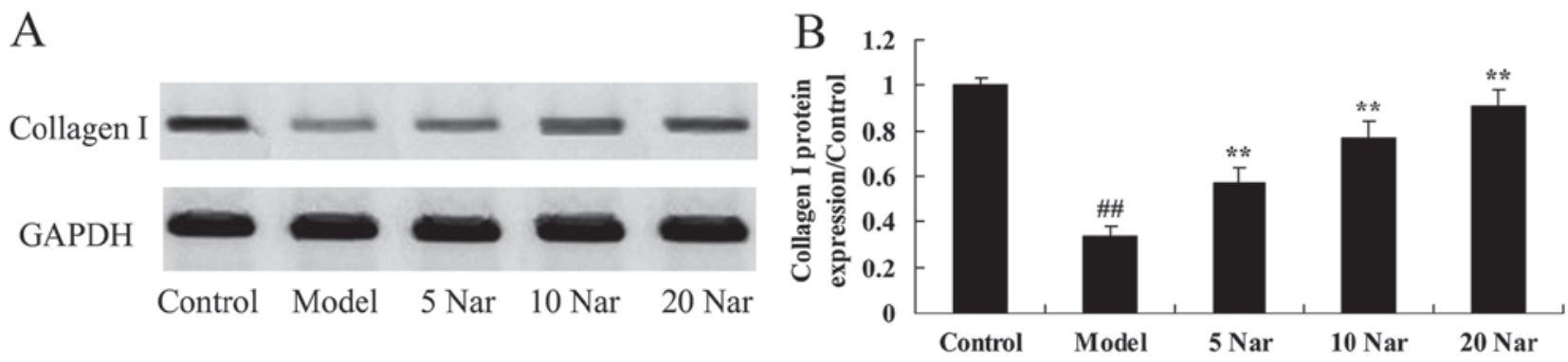

Figure 7. Protective effects of naringin on collagen I protein expression. The effect of treatment with naringin on collagen I protein expression, as demonstrated by (A) western blotting and (B) densitometric analysis. ${ }^{\# /} \mathrm{P}<0.01$ vs. control group; ${ }^{* *} \mathrm{P}<0.01$ vs. model group; Control, control group; Model, steroid-induced avascular necrosis of the femoral head model group; Nar, naringin; $5 \mathrm{Nar}, 5 \mathrm{mg} / \mathrm{kg}$ naringin treatment group; $10 \mathrm{Nar}, 10 \mathrm{mg} / \mathrm{kg}$ naringin treatment group; $20 \mathrm{Nar}, 20 \mathrm{mg} / \mathrm{kg}$ naringin treatment group.
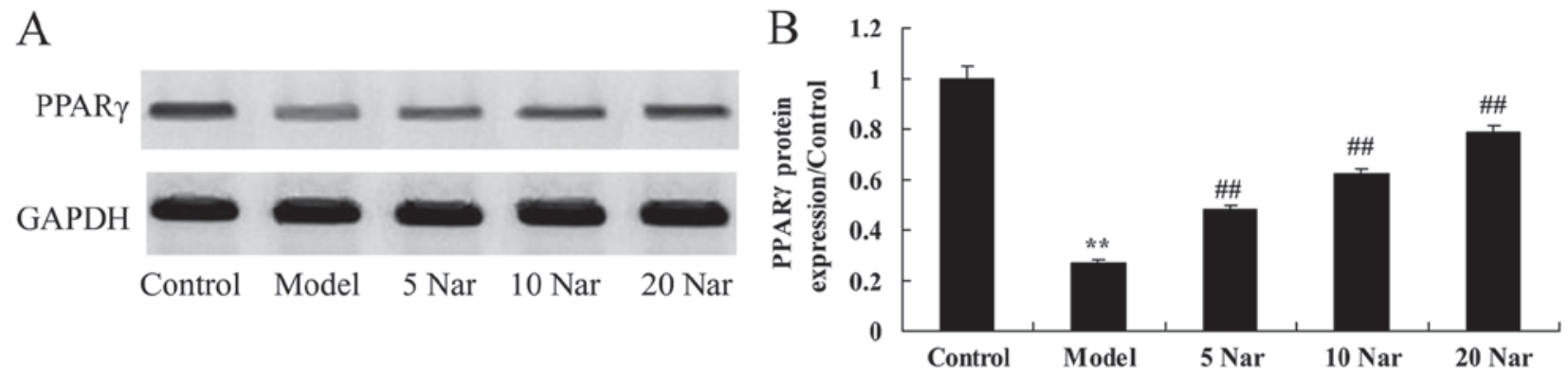

Figure 8. Protective effects of Naringin on PPAR $\gamma$ protein expression. The effect of treatment with naringin on PPAR $\gamma$ protein expression, as demonstrated by (A) western blotting and (B) densitometric analysis. ${ }^{* *} \mathrm{P}<0.01$ vs. control group; ${ }^{\# \#} \mathrm{P}<0.01$ vs. model group. PPAR $\gamma$, peroxisome proliferator-activated receptor $\gamma$; Control, control group; Nar, naringin; Model, steroid-induced avascular necrosis of the femoral head model group; $5 \mathrm{Nar}, 5 \mathrm{mg} / \mathrm{kg}$ naringin treatment group; $10 \mathrm{Nar}, 10 \mathrm{mg} / \mathrm{kg}$ naringin treatment group; $20 \mathrm{Nar}, 20 \mathrm{mg} / \mathrm{kg}$ naringin treatment group.

A

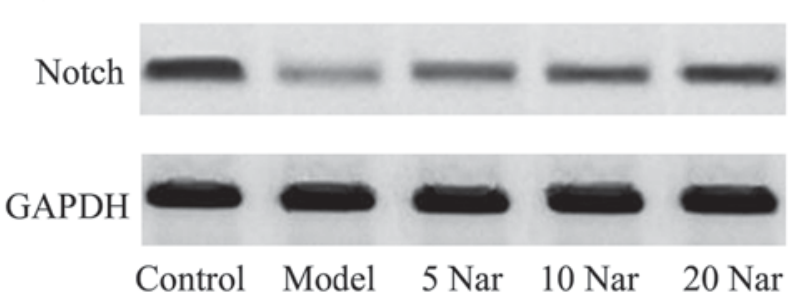

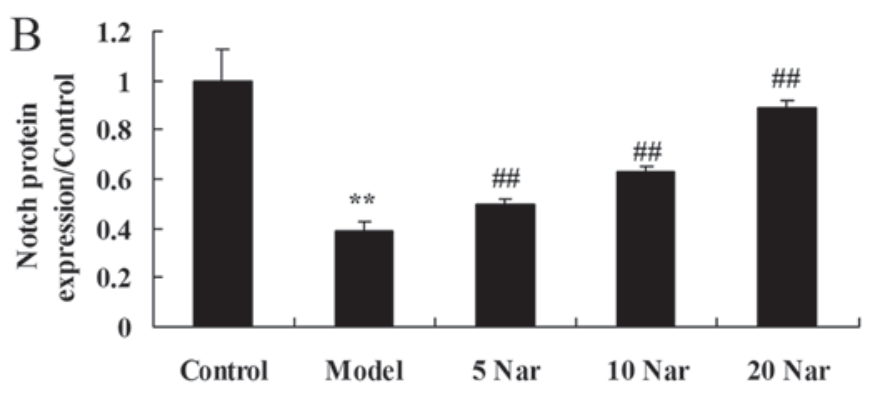

Figure 9. Protective effects of Naringin on Notch protein expression. The effect of treatment with naringin on Notch protein expression, as demonstrated by (A) western blotting and (B) densitometric analysis. ${ }^{* *} \mathrm{P}<0.01$ vs. control group; ${ }^{\# \#} \mathrm{P}<0.01$ vs. model group. Notch, neurogenic locus notch homolog protein; Control, control group; Nar, naringin; Model, steroid-induced avascular necrosis of the femoral head model group; $5 \mathrm{Nar}, 5 \mathrm{mg} / \mathrm{kg}$ naringin treatment group; $10 \mathrm{Nar}, 10 \mathrm{mg} / \mathrm{kg}$ naringin treatment group; $20 \mathrm{Nar}, 20 \mathrm{mg} / \mathrm{kg}$ naringin treatment group.

Protective effects of naringin on Notch protein expression. In the present study, it was demonstrated that the protein expression of Notch protein in the SANFH rabbit model group was decreased compared with the control group (Fig. 9). Treatment with naringin significantly induced Notch protein expression in the SANFH rabbit, compared with the SANFH model group (Fig. 9).

Protective effects of naringin on $\beta$-catenin protein expression. In the SANFH rabbit model group, $\beta$-catenin protein expression was significantly suppressed compared with the control group (Fig. 10). The inhibition of $\beta$-catenin protein expression in SANFH rabbit was significantly reversed by naringin, compared with the SANFH model group (Fig. 10).
Protective effects of naringin on $p$-AKT protein expression. Compared with the control group, p-Akt protein expression in the SANFH rabbit model group was decreased (Fig. 11). Naringin significantly enhanced the p-Akt protein expression in the SANFH rabbit, compared with the SANFH model group (Fig. 11).

\section{Discussion}

Clinically, treatment with large doses of hormones in the long-term is frequently associated with underlying diseases, including systemic lupus erythematosus, anti-phospholipid antibody syndrome, rheumatoid arthritis, leukemia and other diseases, all of which share a common pathological process; 

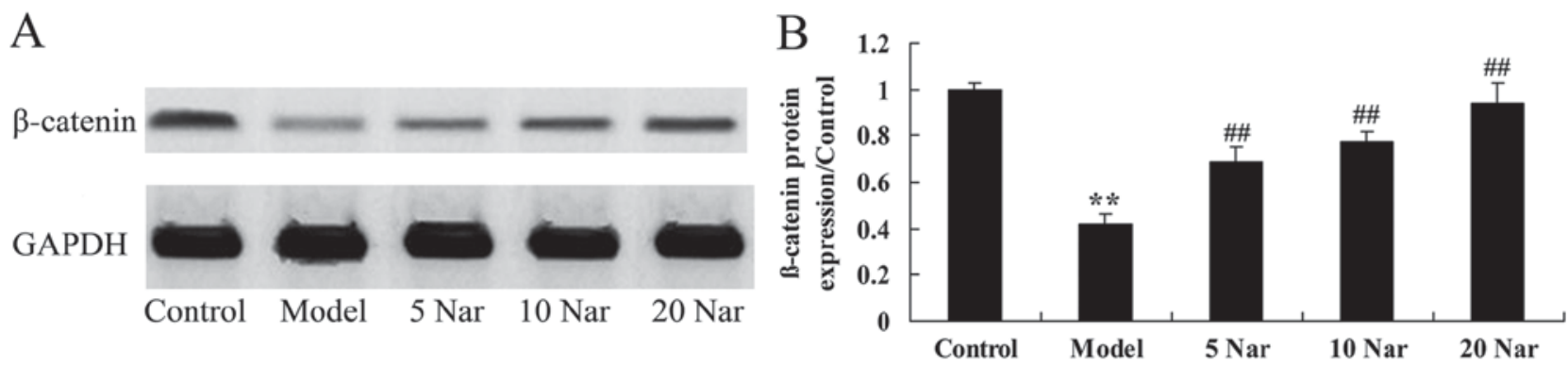

Figure 10. Protective effects of Naringin on $\beta$-catenin protein expression. The effect of treatment with naringin on $\beta$-catenin protein expression, as demonstrated by (A) western blotting and (B) densitometric analysis. ${ }^{* *} \mathrm{P}<0.01$ vs. control group; ${ }^{\# \#} \mathrm{P}<0.01$ vs. model group. Control, control group; Model, steroid-induced avascular necrosis of the femoral head model group; Nar, naringin; $5 \mathrm{Nar}, 5 \mathrm{mg} / \mathrm{kg}$ naringin treatment group; $10 \mathrm{Nar}, 10 \mathrm{mg} / \mathrm{kg}$ naringin treatment group; $20 \mathrm{Nar}, 20 \mathrm{mg} / \mathrm{kg}$ naringin treatment group.
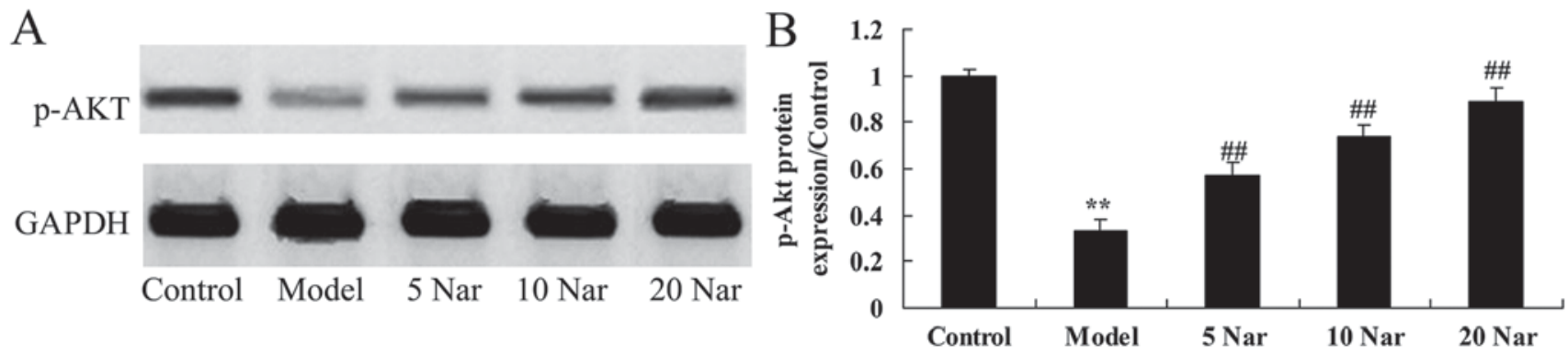

Figure 11. Protective effects of Naringin on p-AKT protein expression. The effect of treatment with naringin on p-AKT protein expression, as demonstrated by (A) western blotting and (B) densitometric analysis. ${ }^{* *} \mathrm{P}<0.01$ vs. control group; ${ }^{\# \#} \mathrm{P}<0.01$ vs. model group. Control, control group; Model, steroid-induced avascular necrosis of the femoral head model group; Nar, naringin; p-AKT, phosphorylated Rac- $\alpha$ serine/threonine protein kinase; $5 \mathrm{Nar}, 5 \mathrm{mg} / \mathrm{kg}$ naringin treatment group; $10 \mathrm{Nar}, 10 \mathrm{mg} / \mathrm{kg}$ naringin treatment group; $20 \mathrm{Nar}, 20 \mathrm{mg} / \mathrm{kg}$ naringin treatment group.

namely, that they may result in vascular endothelial injury and blood alterations, leading to a hypercoagulable state (17). Therefore, the pathogenesis of SANFH may be associated with large doses of hormones used to treat the original vascular disease, which eventually leads to bone necrosis (18). A previous study demonstrated that the use of hormones alone is insufficient to induce the animal model of $\mathrm{FH}$ (19). A previous study regarding animal model establishment demonstrated that a variety of drugs in combination with hormones results in the ideal animal model of SANFH (20). The results of the present study indicated that naringin significantly protected against steroid-induced increases in serum osteocalcin levels, osteonecrosis incidence, total cholesterol and LDL/HDL ratio in SANFH rabbits.

Glucocorticoids are frequently used to treat serious infectious diseases clinically, including rheumatoid arthritis and systemic lupus erythematosus (21). However, for patients with long-term use of corticosteroids, severe osteoporosis and $\mathrm{FH}$ may occur (22). During the in vitro culture of osteoblasts, dexamethasone exhibits two-way regulation of osteoblast differentiation and mineralization, which depends on the maturation stage, the number of cells, and the drug concentration and time of treatment (23). Therefore, glucocorticoids are an inhibitor of osteoblast differentiation and maturation in vitro (24). An in vivo study into necrosis of the femoral head in steroid-induced FH rats demonstrated that gene and protein expression of RUNX and OSX is altered and its association with bone synthesis metabolism subsequently investigated (24). The FH rat model was established via gluteal injection of corticosteroids and forced load exercises, and the results demonstrated that the gene expression and protein synthesis of RUNX and OSX decrease over time, indicating that, in the early stages of SANFH, the gene and protein expression of RUNX and OSX in the rat femoral head decrease, inhibiting bone formation (25). Additionally, the results of the present study suggested that naringin significantly increased RUNX2 and OSX mRNA expression and ALP activity in the SANFH rabbit.

Studies have demonstrated that the adipogenesis of bone marrow stromal cells is additionally characterized by a marked increase in the expression of PPAR $\gamma$, consistent with other lipocyte differentiation models $(5,8)$. The increased expression of PPAR $\gamma$ directly activates or induces the gene expression profile of the majority of adipocyte phenotypes, including fatty acid synthase, glutamic acid 4, acetyl coenzyme A and shuttle enzymes (26). However, the overexpression of PPAR $\gamma$ in vitro inhibits the formation of fat cells and promotes the formation of osteoblasts, leading to an increase in trabecular bone (27). Studies have demonstrated that when PPAR $\gamma$ genes are selectively knocked out of fat cells, the function of fat cells is severely degraded, leading to progressive lipodystrophy, insulin resistance and other metabolic diseases $(27,28)$. Fat formation is impaired in PPAR $\gamma$-knockout mice. In the process of fat formation, PPAR $\gamma$ requires the involvement of transcription factor ligands in order to increase in expression, and these ligands include natural ligands and synthetic ligands (29). ARY is the essential transcription factor for the differentiation of bone marrow stromal cells into adipocytes, and serves 
an important role (5). PPAR $\gamma$ is regulated by a variety of cytokines in the regulation of adipocyte formation, and these factors promote increased expression of PPAR $\gamma$, in order to increase the differentiation of bone marrow fat cells and result in a decrease in the differentiation of bone marrow stromal cells to osteoblasts which eventually results in necrosis of the femoral head (25). In the present study, naringin was observed to significantly promote PPAR $\gamma$ protein expression in the SANFH rabbit model.

However, the mechanisms underlying the effect of estrogen treatment on postmenopausal osteoporosis, and the regulation of mesenchymal stem cell osteogenic differentiation, remain unclear (30). The Notch signaling pathway is a highly-conserved signaling pathway involved in cell differentiation, self-renewal and apoptosis (31). At present, research into estrogen and the Notch signaling pathway has predominantly focused on human tumors and brain development (32). There are relatively few studies regarding the effect of estrogen on differentiation and proliferation via its impact on the Notch signaling pathway, in the differentiation of human bone marrow mesenchymal stem cells (33). The results of the present study demonstrated that naringin significantly suppressed Notch protein expression and promoted the $\beta$-catenin and $\mathrm{p}$-Akt protein expression in the SANFH rabbit.

In the present study, it was demonstrated that naringin notably protected against steroid-induced decreased serum osteocalcin level, and increased osteonecrosis incidence, total cholesterol and LDL/HDL in the SANFH rabbit. It was additionally demonstrated that naringin significantly inhibited caspase- 3 activity, increased RUNX2 and OSX mRNA expression, promoted ALP activity and upregulated collagen I protein expression in the SANFH rabbit, through regulation of PPAR $\gamma$, Notch, $\beta$-catenin and $\mathrm{p}$-AKT protein expression. The results of the present study suggested that naringin may be potentially applied in the clinic to achieve effective treatment of FH.

\section{Acknowledgements}

This study was supported by Zhejiang Provincial Natural Science Foundation of China (LY17H270006).

\section{References}

1. Aoyama T, Goto K, Kakinoki R, Ikeguchi R, Ueda M, Kasai Y, Maekawa T, Tada H, Teramukai S, Nakamura T and Toguchida J: An exploratory clinical trial for idiopathic osteonecrosis of femoral head by cultured autologous multipotent mesenchymal stromal cells augmented with vascularized bone grafts. Tissue Eng Part B Rev 20: 233-242, 2014.

2. Ma Y, Wang T, Liao J, Gu H, Lin X, Jiang Q, Bulsara MK, Zheng $\mathrm{M}$ and Zheng Q: Efficacy of autologous bone marrow buffy coat grafting combined with core decompression in patients with avascular necrosis of femoral head: A prospective, double-blinded, randomized, controlled study. Stem Cell Res Ther 5: 115, 2014.

3. Lubbers M, Coenen A, Bruning T, Galema T, Akkerhuis J, Krenning B, Musters P, Ouhlous M, Liem A, Niezen A, et al: Sex differences in the performance of cardiac computed tomography compared with functional testing in evaluating stable chest pain: Subanalysis of the multicenter, randomized CRESCENT trial (calcium imaging and selective CT angiography in comparison to functional testing for suspected coronary artery disease). Circ Cardiovasc Imaging 10: pii: e005295, 2017.
4. Pintér Ö, Hardi P, Nagy T, Gasz B, Kovács V, Arató E, Sínay L, Lénárd L and Jancsó G: The role of GST polymorphism in reperfusion induced oxidative stress, inflammatory responses and clinical complications after surgical and percutaneous coronary intervention. Clin Hemorheol Microcirc 66: 261-272, 2017.

5. Zhang J, Wang M, Li Z, Bi X, Song J, Weng S and Fu G: NADPH oxidase activation played a critical role in the oxidative stress process in stable coronary artery disease. Am J Transl Res 8: 5199-5210, 2016.

6. Prasad K and Dhar I: Oxidative stress as a mechanism of added sugar-induced cardiovascular disease. Int J Angiol 23: 217-226, 2014.

7. Riegersperger M, Covic A and Goldsmith D: Allopurinol, uric acid, and oxidative stress in cardiorenal disease. Int Urol Nephrol 43: 441-449, 2011.

8. Turan T, Menteşe Ü, Ağaç MT, Akyüz AR, Kul S, Aykan AÇ, Bektaş H, Korkmaz L, Öztaş Menteşe S, Dursun İ and Çelik Ş: The relation between intensity and complexity of coronary artery lesion and oxidative stress in patients with acute coronary syndrome. Anatol J Cardiol 15: 795-800, 2015.

9. Xiao C, Hanlon A, Zhang Q, Movsas B, Ang K, Rosenthal DI, Nguyen-Tan PF, Kim H, Le Q and Bruner DW: Risk factors for clinician-reported symptom clusters in patients with advanced head and neck cancer in a phase 3 randomized clinical trial: RTOG 0129. Cancer 120: 848-854, 2014.

10. Zhu Y, Shi LY,Lei YM, Bao YH, Li ZY, Ding F,Zhu GT, Wang QQ and Huang CX: Radiosensitization effect of hsa-miR-138-2-3p on human laryngeal cancer stem cells. PeerJ 5: e3233, 2017.

11. Chen S, Sun YY, Zhang ZX, Li YH, Xu ZM and Fu WN: Transcriptional suppression of microRNA-27a contributes to laryngeal cancer differentiation via GSK-3 $\beta$-involved Wnt/ $\beta$-catenin pathway. Oncotarget 8: 14708-14718, 2017.

12. He Q, Tian L, Jiang H, Zhang J, Li Q, Sun Y, Zhao J, Li H and Liu M: Identification of laryngeal cancer prognostic biomarkers using an inflammatory gene-related, competitive endogenous RNA network. Oncotarget 8: 9525-9534, 2017.

13. Li P, Liu H, Wang Z, He F, Wang H, Shi Z, Yang A and Ye J: MicroRNAs in laryngeal cancer: Implications for diagnosis, prognosis and therapy. Am J Transl Res 8: 1935-1944, 2016.

14. Janssens GO, Rademakers SE, Terhaard CH, Doornaert PA, Bijl HP, van den Ende P, Chin A, Marres HA, de Bree R, van der Kogel AJ, et al: Accelerated radiotherapy with carbogen and nicotinamide for laryngeal cancer: Results of a phase III randomized trial. J Clin Oncol 30: 1777-1783, 2012.

15. Geng J, Liu Y, Jin Y, Tai J, Zhang J, Xiao X, Chu P, Yu Y, Wang SC, Lu J, et al: MicroRNA-365a-3p promotes tumor growth and metastasis in laryngeal squamous cell carcinoma. Oncol Rep 35: 2017-2026, 2016.

16. Livak KJ and Schmittgen TD: Analysis of relative gene expression data using real-time quantitative PCR and the 2(-Delta Delta C(T)) method. Methods 25: 402-408, 2001.

17. Yu J, Wang L, Akinyi M, Li Y, Duan Z, Zhu Y and Fan G: Danshensu protects isolated heart against ischemia reperfusion injury through activation of Akt/ERK1/2/Nrf2 signaling. Int J Clin Exp Med 8: 14793-14804, 2015.

18. Zhong Y, Cheng CF, Luo YZ, Tian CW, Yang H, Liu BR, Chen MS, Chen YF and Liu SM: C-reactive protein stimulates RAGE expression in human coronary artery endothelial cells in vitro via ROS generation and ERK/NF- $\mathrm{KB}$ activation. Acta Pharmacol Sin 36: 440-447, 2015.

19. Yang J, Zeini M, Lin CY, Lin CJ, Xiong Y, Shang C, Han P, Li W, Quertermous T, Zhou B and Chang CP: Epicardial calcineurin-NFAT signals through Smad2 to direct coronary smooth muscle cell and arterial wall development. Cardiovasc Res 101: 120-129, 2014.

20. Crobu F, Palumbo L, Franco E, Bergerone S, Carturan S, Guarrera S, Frea S, Trevi G, Piazza A and Matullo G: Role of TGF-betal haplotypes in the occurrence of myocardial infarction in young Italian patients. BMC Med Genet 9: 13, 2008.

21. Nakata Y, Ijichi K, Hanai N, Nishikawa D, Suzuki H, Hirakawa H, Kodaira T, Fujimoto Y, Fujii T, Miyazaki T, et al: Treatment results of alternating chemoradiotherapy with early assessment for advanced laryngeal cancer: A multi-institutional phase II study. Auris Nasus Larynx 44: 104-110, 2017.

22. Weng M, Ding M, Xu Y, Yang X, Li L, Zhong J and Miao C: An evaluation of thyromental distance-based method or weight-based method in determining the size of the laryngeal mask airway supreme: A randomized controlled study. Medicine (Baltimore) 95: e2902, 2016. 
23. Zhang J, Kuai X, Song M, Chen X, Yu Z, Zhang H and Mao Z: microRNA-32 inhibits the proliferation and invasion of the SGC-7901 gastric cancer cell line in vitro. Oncol Lett 7: 270-274, 2014.

24. Andreadis C,Iliopoulou C, Sidiras T, Boutis A,Diamantopoulos N, Vahtsevanos K, Gennatas K and Mouratidou D: Neoadjuvant chemotherapy followed by radiotherapy versus concurrent chemoradiotherapy for larynx preservation in patients with advanced laryngeal cancer. J BUON 12: 341-347, 2007.

25. Saito I, Azuma K, Kakikawa T, Oshima N, Hanson ME and Tershakovec AM: A randomized, double-blind, placebo-controlled study of the effect of ezetimibe on glucose metabolism in subjects with type 2 diabetes mellitus and hypercholesterolemia. Lipids Health Dis 14: 40, 2015.

26. Tuomi L, Andréll P and Finizia C: Effects of voice rehabilitation after radiation therapy for laryngeal cancer: A randomized controlled study. Int J Radiat Oncol Biol Phys 89: 964-972, 2014

27. Zhang H, Jiang Y, Nguyen HD, Poo DC and Wang W: The effect of a smartphone-based coronary heart disease prevention (SBCHDP) programme on awareness and knowledge of $\mathrm{CHD}$, stress, and cardiac-related lifestyle behaviours among the working population in Singapore: A pilot randomised controlled trial. Health Qual Life Outcomes 15: 49, 2017.

28. Salfati E, Nandkeolyar S, Fortmann SP, Sidney S, Hlatky MA, Quertermous T, Go AS, Iribarren C, Herrington DM, Goldstein BA and Assimes TL: Susceptibility loci for clinical coronary artery disease and subclinical coronary atherosclerosis throughout the life-course. Circ Cardiovasc Genet 8: 803-811, 2015
29. Ammenwerth E, Woess S, Baumgartner C, Fetz B, van der Heidt A, Kastner P, Modre-Osprian R, Welte S and Poelzl G: Evaluation of an integrated telemonitoring surveillance system in patients with coronary heart disease. Methods Inf Med 54: 388-397, 2015.

30. Kapral M, Strzalka B, Kowalczyk M, Jurzak M, Mazurek U, Gierek T, Paluch J, Markowski J, Swiatkowska L and Weglarz L: Transforming growth factor beta isoforms (TGF-beta1, TGF-beta2, TGF-beta3) messenger RNA expression in laryngeal cancer. Am J Otolaryngol 29: 233-237, 2008.

31. Park SJ, Jin ML, An HK, Kim KS, Ko MJ, Kim CM, Choi YW and Lee YC: Emodin induces neurite outgrowth through PI3K/Akt/GSK-3 $\beta$-mediated signaling pathways in Neuro2a cells. Neurosci Lett 588: 101-107, 2015.

32. Li H, Yang T, Zhou H, Du J, Zhu B and Sun Z: Emodin combined with nanosilver inhibited sepsis by anti-inflammatory protection. Front Pharmacol 7: 536, 2017.

33. Huang YQ, Huang GR, Wu MH, Tang HY, Huang ZS, Zhou XH, Yu WQ, Su JW, Mo XQ, Chen BP, et al: Inhibitory effects of emodin, baicalin, schizandrin and berberine on hefA gene: Treatment of Helicobacter pylori-induced multidrug resistance. World J Gastroenterol 21: 4225-4231, 2015. 